\title{
A calculation of potential rice yields
}

\author{
A. van Ittersum
}

Internationaal Land Development Consultants N.V. (ILACO), Arnhem, the Netherlands

Received: 20 July 1971

\section{Summary}

Gross photosynthesis of three rice varieties has been calculated according to de Wit (1965).

Results have been used to estimate total dry matter production of these varieties, which were cultivated at the International Rice Research Institute (IRRI) in Los Baños in four different seasons during 1962/1963.

Grain yields were calculated by means of a tracing experiment on the transport of carbohydrates produced in three different growth stages of the rice plant to the grain. The calculated total dry matter, the grain yield and the grain/straw ratios agree accepably to the experimental results, provided it is known when the crop closes and when the growth rate starts to decrease.

Thus potential rice yields have been calculated for a modern non-lodging and nonphotosensitive IRRI-variety on a number of relevant latitudes for different seasons, taking only solar radiation as a limiting factor.

\section{Photosynthesis of the rice crop}

To calculate the gross photosynthesis of a closed green crop surface de Wit (1965) developed a model in which one of the main starting-points is the photosynthesis function of a single leaf in normal air with a constant temperature. This function gives the relationship between the light intensity expressed in $\mathrm{cal} \mathrm{cm}^{-2} \mathrm{~min}^{-1}$ and the production of carbohydrates in $\mathrm{kg} \mathrm{ha}^{-1} \mathrm{~h}^{-1}$. The course of this relationship is determined by the nature of the crop and it must, therefore, be established experimentally, especially the slope of the curve and the assimilation rate at very high light intensities, called AMAX (see Fig. 1).

The daily total assimilation of a closed green crop surface is then to be calculated by estimating the light interception in every layer of leaves by combining the leaf distribution function and the light distribution function. The former implies the cumulative frequency distribution of angles between leaves and soil surface, the latter the distribution of direct and diffuse light during the day taking into account the latitude and the time of the year. Plant spacing and amount and size of leaves are defined by the Leaf Area Index (LAI), i.e. the total leaf surface per unit of soil surface. As the light penetrates the canopy, its intensity shows a more or less exponential decrease as the LAI increases, so it is the upper layers of leaves that mainly contribute to the photosynthesis of the crop as a whole. In cereals the LAI may approach 5.

The amount of solar radiation in the photosynthetic active region is called $\mathrm{HC}$ in the case of perfectly clear days; on totally overcast days the active amount is estimated at 


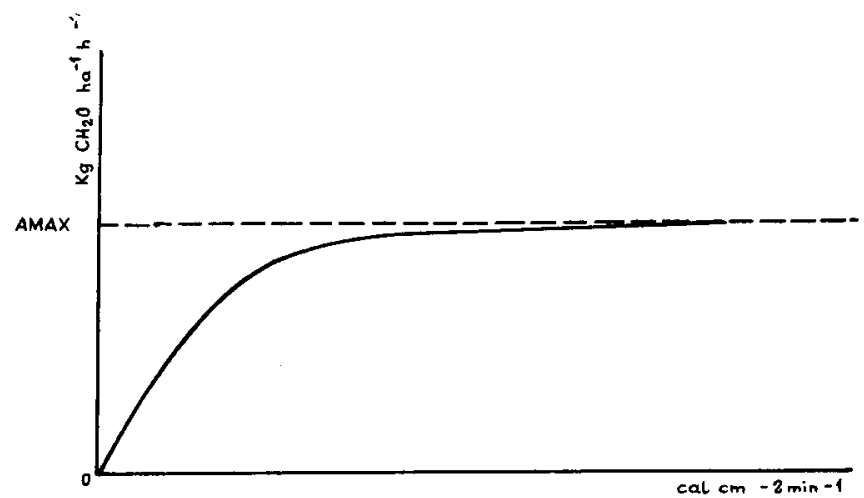

Fig. 1. Photosynthesis function of a single leaf according to de Wit (1965).

$0.2 \mathrm{HC} . \mathrm{HC}$ is expressed in cal $\mathrm{cm}^{-2} \mathrm{day}^{-1}$. In practice, the active radiation amounts to $50 \%$ of the total short-wave radaition (= SWR) as measured by a solar radiation integrator, thus:

$$
0.5 \times \mathrm{SWR}=\mathrm{F} \times 0.2 \times \mathrm{HC}+(1-\mathrm{F}) \times \mathrm{HC} \mathrm{cal} \mathrm{cm} \mathrm{cday}^{-1}
$$

$\mathrm{F}$ being the fraction of the day-time when the sky is overcast. The daily gross photosynthesis of a crop surface, characterized by a set of standard variables, can be calculated for perfectly clear days as well as for totally overcast days, called PC and PO respectively, and both expressed in $\mathrm{kg}$ carbohydrates per ha per day. The real daily gross photosynthesis (= GP) is thus:

$$
\mathrm{GP}=\mathrm{F} \times \mathrm{PO}+(1-\mathrm{F}) \times \mathrm{PC} \mathrm{kg} \text { carbohydrates ha-1 day-1 }
$$

so if the total short wave radiation is known, the $\mathrm{F}$ factor is calculated by Eq 1 and the actuel daily gross photosynthesis by Eq. 2 .

For every month and every 10 degrees of latitude the $\mathrm{HC}, \mathrm{PC}$ and $\mathrm{PO}$ are given in Table 6 of de Wit (1965).

With the exception of the maximum photosynthesis rate of a single leaf, AMAX, de Wit's standard conditions are supposed to be in agreement with those of a closed rice crop.

De Wit takes AMAX $=20 \mathrm{~kg} \mathrm{ha}^{-1} \mathrm{~h}^{-1}$ as a standard value, but the AMAX values for the rice varieties to be discussed (Table 1 ) could be deducted from maximum $\mathrm{CO}_{2}$ assi-

\begin{tabular}{|c|c|c|c|}
\hline Variety & $\begin{array}{l}N \text { content } \\
\text { of the leaf } \\
\left(\mathrm{mg} \mathrm{cm}^{-2}\right)\end{array}$ & $\begin{array}{l}\mathrm{CO}_{2} \text { uptake } \\
\left(\mathrm{mg} 100 \mathrm{~cm}^{-2} \mathrm{~h}^{-1}\right)\end{array}$ & $\begin{array}{l}\operatorname{AMAX} \\
\left(\mathrm{kg} \mathrm{CH}_{2} \mathrm{O} \mathrm{ha}^{-1} \mathrm{~h}^{-1}\right)\end{array}$ \\
\hline 'Tainan-3' & 220 & 35.3 & 24 \\
\hline 'Peta' & 184 & 46.7 & 32 \\
\hline 'BPI-76' & 220 & 47.1 & 32 \\
\hline 'IR-8' & 203 & 47.0 & 32 \\
\hline
\end{tabular}

Table 1. AMAX values for the varieties discussed. 


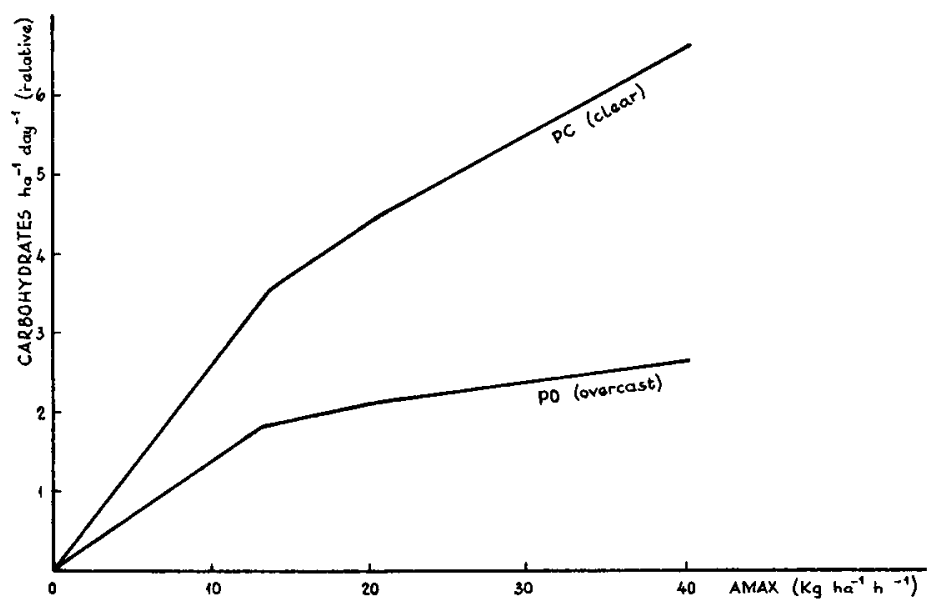

Fig.2. Effect of the maximum photosynthesis of single leaves, AMAX, on the photosynthesis of a closed green crop for perfectly clear and overcast days under otherwise standard conditions (after de Wit, 1965).

milation rates mentioned by the International Rice Research Institute (IRRI) (Anon., 1968). These values average between $0 \mathrm{~kg} \mathrm{~N}$ and $100 \mathrm{~kg} \mathrm{~N}$ per ha.

The effect of higher AMAX on the daily totals of gross photosynthesis PC and PO is shown, ceteris paribus, in Fig. 2, which is based on Table 7 of de Wit (1965).

The figure shows that $\mathrm{a} \%$ increase of AMAX in relation to AMAX $=20$, leads to about a $2 \%$ increase of $\mathrm{PC}$ and to about a $5 \%$ increase of PO. Hence, the gross photosynthesis as found from de Wit's Table 6 (1965) using Eq. 1 and 2 must be increased by:

$$
\frac{\mathrm{a} / 5}{100} \times \mathrm{F} \times \mathrm{PO}+\frac{\mathrm{a} / 2}{100} \times(1-\mathrm{F}) \times \mathrm{PC}
$$

\section{Available data}

At the IRRI at Los Baños $\left(14^{\circ} \mathrm{N}\right)$ three rice varieties were planted in four different seasons during 1962/1963 to demonstrate seasonal effects on total dry matter production and grain yield (Tanaka et al., 1964). The experiment provided sufficient data to compare theoretical calculations with the experimental results. The varieties used were:

a) 'Tainan-3', japonica, non-photosensitive

b) 'Peta', indica, slightly photosensitive

c) 'BPI-76', indica , very photosensitive

Plant spacing was $30 \times 30 \mathrm{~cm}$. Fertilizers at rates of $40 \mathrm{~kg} \mathrm{~N} / \mathrm{ha}, 17 \mathrm{~kg} \mathrm{P} / \mathrm{ha}$ and $33 \mathrm{~kg}$ $\mathrm{K} / \mathrm{ha}$ were mixed through the topsoil one day before transplanting. Irrigation lasted till full maturity of the grain. Insecticides were sprayed weekly and weeds removed by hand, if necessary. In case of lodging the plants of four hills were tied together.

Samples were weighed after drying in a forced draft oven at $70^{\circ} \mathrm{C}$ for 1 or 2 days, leaving about $3 \%$ moisture. Except in December, January and February the average 


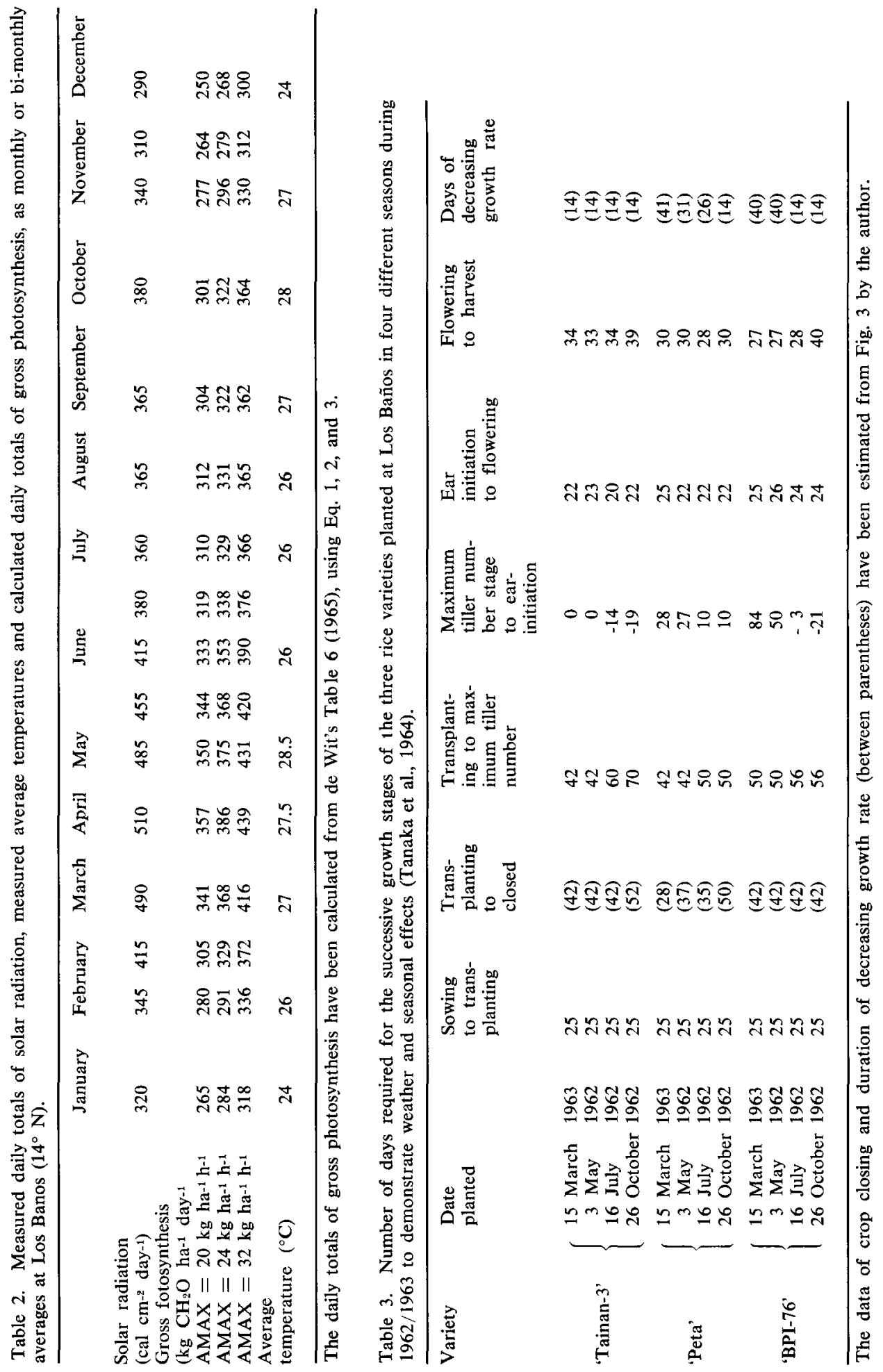


temperatures showed little variation. Solar radiation data of the seasons concerned were available for the period December 1962 to October 1963. Supplementary data were obtained from, averages for the years 1959-1963 (Anon., 1967).

The measured daily total radiation, the calculated daily gross photosynthesis corresponding with $\mathrm{AMAX}=20,24$ and $32 \mathrm{~kg} \mathrm{ha}^{-1} \mathrm{~h}^{-1}$, as well as the average temperatures are given in Table 2, as average values per month, or per 15 days if wide variations occurred.

\section{Dry matter production}

During the period of vigorous growth of the rice crop the net photosynthesis $(=N P$ ) amounts to about $60 \%$ of the gross photosynthesis, about $40 \%$ of it being respired (Tanaka et al. 1966).

Assuming, furthermore, that the weight percentage of carbohydrates needed for root growth when the crop is closed equals about the weight percentage of minerals in the straw, the growth rate of above ground parts equals about the net photosynthesis. In the period July-November these growth rates are theoretically about $190 \mathrm{~kg} \mathrm{ha}^{-1} \mathrm{day}^{-1}$ for 'Tainan-3', and about $215 \mathrm{~kg} \mathrm{ha}^{-1}$ day-1 $^{-1}$ for 'Peta' and 'BPI-76' at Los Baños.

For comparison purposes, the growth curves as found in the experiment are shown in Fig. 3. The growth rates of $190 \mathrm{~kg} \mathrm{ha}^{-1} \mathrm{day}^{-1}$ and $215 \mathrm{~kg} \mathrm{ha}^{-1} \mathrm{day}^{-1}$ have been drawn in by the author.

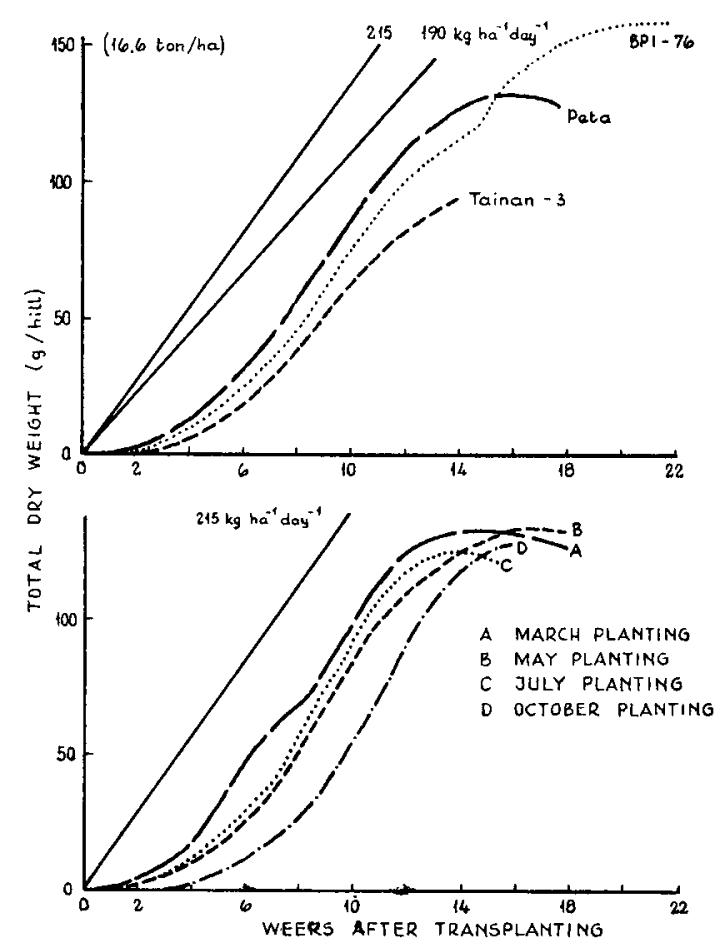

14
Fig. 3 Total dry weight of aboveground parts in the successive growth stages of three varieties, planted in May (top) and of the variety 'Peta', planted in four different seasons (bottom), IRRI, 1962/1963 (Tanaka et al., 1964). 
The steep part of the curves, between the moment when the crop is closed and the growth rate starts decreasing, fits well to a straight line. The dry matter produced before closing is about $1600 \mathrm{~kg} / \mathrm{ha}$, a value found for most cereals. The declining of the curves has been accounted for in the calculations by assuming a linear decrease in the net photosynthesis during a certain period, being observed in wheat by de Wit (1958).

The strong decline in the growth curves of the indica varieties 'Peta' and 'BPI-76' must then be attributable to destruction processes in (many) shed leaves.

The total straw production of the March, May and June plantings of these two varieties has, therefore, been reduced by $20 \%$. This reduction have not been necessary for the October plantings, probably owing to the relatively low average temperatures during their ripening phases. The exact number of days required for the successive growth stages are given in Table 3.

For every growth cyclus the total dry matter in the above ground parts can be calculated as follows:

$$
\left(1600+N P_{a} \times a+N P_{b} \times b \times 1 / 2\right) \times \frac{100}{85} \mathrm{~kg} / \mathrm{ha} \quad(15 \% \text { moisture }),
$$

in which: $\mathrm{NP}_{\mathrm{a}}=$ weighed average net photosynthesis in the period of linear growth; a $=$ number of days in that period of linear growth; $\mathbf{N P}_{\mathrm{b}}=$ weighed average net photosynthesis in the period of decreasing growth rate; $b=$ number of days of decreasing growth rate.

\section{Contribution to the grain}

Shen Lian and Tanaka (1967) fed radio-active carbon dioxide, C14 instead of $\mathrm{C}^{12}$, to rice plants of the 'Peta' variety in three different stages of growth. For each stage the percentages finally observed in the grain ( $=$ brown rice + husk) were:

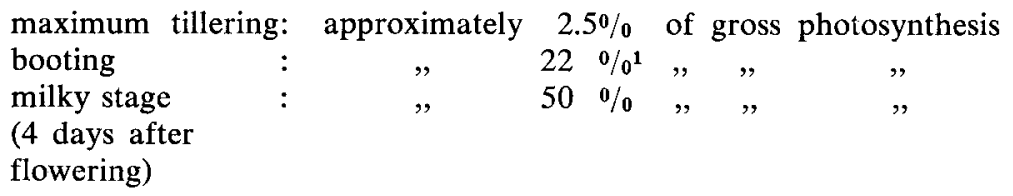

At the same time Fig. 4 shows an increase of carbohydrates in the straw before flowering folllowed by a strong decrease after flowering, both effects being stronger in the indicas 'Peta' and 'BPI-76', than in the japonica 'Tainan-3', indicated by the broken lines.

At each point of time in the growth cyclus of the three varieties the total dry matter can be read from Fig. 3, whilst the straw weight can be estimated by subtracting the panicle weight. By combining Fig. 3 and 4, the average percentage of the daily net photosynthesis, causing the carbohydrate accumulation in the straw can be calculated. Furthermore, it has been assumed that the accumulation is proportional only to the transport to the brown rice, as the husk is formed mainly before flowering and is supposed to absorb the same fraction of the net photosynthesis in each variety. Thus a combination of the percentages of translocation, found by Shen Lian and Tanaka (1967), with the informations obtained from the Fig. 3 and 4, leads to the following estimate of

$113 \%$ in the 'husk' $+9 \%$ in the 'brown rice'. 


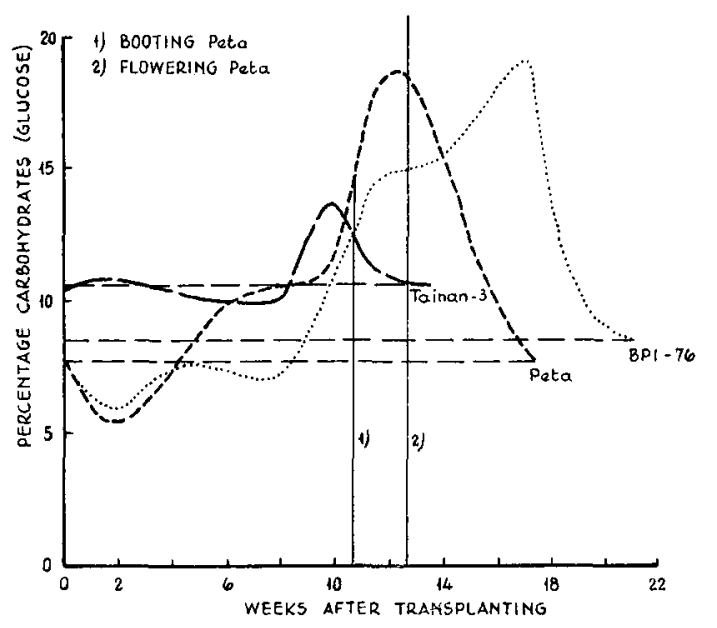

Fig. 4. Percentage of carbohydrates in the straw of three rice varieties planted in May 1963 at the IRRI (Tanaka et al., 1964).

the fractions of net photosynthesis produced in three successive stages and finally, translocated to the grain for each of the three varieties. Thet net photosynthesis again being $60 \%$ of the gross photosynthesis (Table 4).

The total grain yield can then be calculated as:

$$
\left(\mathrm{NP}_{\mathrm{c}} \times \mathrm{C} \times \mathrm{X}\right) \times \frac{100}{85} \mathrm{~kg} / \mathrm{ha}(15 \% \text { moisture }) \text {, in which: }
$$

$\mathrm{NP}_{\mathrm{c}}=$ weighed average net photosynthesis in each of the three stages of grain contribution (Note: $\mathrm{NP}=(60 \% \times \mathrm{GP}) \times(100 \%$ till $0 \%)$, owing to eventual decrease in growth. The exact percentage can be read from the linear decrease in NP from $100 \%$ till $0 \%$ during a given number of days (Table 3 ).

$\mathrm{C}=$ number of days in the given stage

$\mathrm{X}=$ fraction contribution to the grain in the given stage.

Table 4. Percentages of net photosynthesis contributed to the grain.

\begin{tabular}{llll}
\hline & $\begin{array}{l}\text { Closed till } \\
\text { panicle } \\
\text { initiation }\end{array}$ & $\begin{array}{l}\text { Panicle initiation } \\
\text { till } \\
\text { milky stage }\end{array}$ & $\begin{array}{l}\text { Milky stage } \\
\text { till } \\
\text { full maturity }\end{array}$ \\
'Tainan-3' & 0 & & \\
'Peta' & 10 & 27 & 83 \\
'BPI-76' & 10 & 37 & 83 \\
& & 32 & 83 \\
\hline
\end{tabular}

\section{The test}

In Table 5 the calculated values of total dry matter, grain production and the resulting grain/straw ratio are given together with those found in the experiment (Tanaka et al., 1964).

Like the theoretical calculations the experimental results have been taken at a $15 \%$ moisture basis; in the original reporting samples were dried to about $3 \%$. Moreover, the 
Table 5. Calculated and experimental values $\left(15 \% \mathrm{H}_{2} \mathrm{O}\right)$ for grain + straw per ha, grain per ha and the grain/straw ratio of the varieties 'Tainan-3', 'Peta' and 'BPI-76' at the IRRI at Los Banos in four seasons during 1962/1963.

\begin{tabular}{|c|c|c|c|c|c|c|c|}
\hline \multirow[t]{2}{*}{ Variety } & \multirow[t]{2}{*}{$\begin{array}{l}\text { Sowing } \\
\text { date }\end{array}$} & \multicolumn{2}{|c|}{$\underset{(\text { ton } / \text { ha) }}{\text { Grain }}+$ straw } & \multicolumn{2}{|c|}{$\begin{array}{l}\text { Grain } \\
\text { (ton/ha) }\end{array}$} & \multicolumn{2}{|c|}{ Grain/straw } \\
\hline & & $\begin{array}{l}\text { calcu- } \\
\text { lated }\end{array}$ & $\begin{array}{l}\text { experi- } \\
\text { mental }\end{array}$ & $\begin{array}{l}\text { calcu- } \\
\text { lated }\end{array}$ & $\begin{array}{l}\text { experi- } \\
\text { mental }\end{array}$ & $\begin{array}{l}\text { calcu- } \\
\text { lated }\end{array}$ & $\begin{array}{l}\text { experi- } \\
\text { mental }\end{array}$ \\
\hline \multirow{4}{*}{ 'Tainan-3' } & 15 March & 13.87 & 13.50 & 6.28 & 5.56 & 0.83 & 0.70 \\
\hline & 3 May & 13.29 & 11.73 & 5.95 & 4.89 & 0.81 & 0.72 \\
\hline & 16 July & 12.12 & 11.85 & 5.44 & 5.80 & 0.81 & 0.96 \\
\hline & 26 October & 13.32 & 11.99 & 6.67 & 6.47 & 1.00 & 1.17 \\
\hline \multirow{4}{*}{ 'Peta' } & ( 15 March & 19.22 & 18.03 & 5.45 & 4.32 & 0.40 & 0.31 \\
\hline & 3 May & 16.74 & 15.26 & 5.58 & 4.91 & 0.50 & 0.48 \\
\hline & 16 July & 15.15 & 14.76 & 5.29 & 3.65 & 0.54 & 0.33 \\
\hline & 26 October & 15.32 & 16.15 & 6.74 & 6.86 & 0.79 & 0.74 \\
\hline \multirow{4}{*}{ 'BPI-76' } & ( 15 March & 27.05 & 26.36 & 5.62 & 5.45 & 0.26 & 0.26 \\
\hline & 3 May & 19.79 & 19.81 & 4.92 & 6.40 & 0.33 & 0.48 \\
\hline & 16 July & 13.86 & 15.01 & 5.87 & 4.79 & 0.74 & 0.48 \\
\hline & 26 October & 13.54 & $7.44^{*}$ & 7.27 & $3.27^{*}$ & 1.16 & $0.78 *$ \\
\hline
\end{tabular}

* In the experiment the October planting of 'BPI-76' did not form a well-closed crop surface.

experimental total dry matter (grain + straw) was expressed in $\mathrm{g} / \mathrm{hill}$ and had to be converted into $\mathrm{kg} / \mathrm{ha}$.

In most cases the calculated values agree acceptably to the experimental ones. Owing
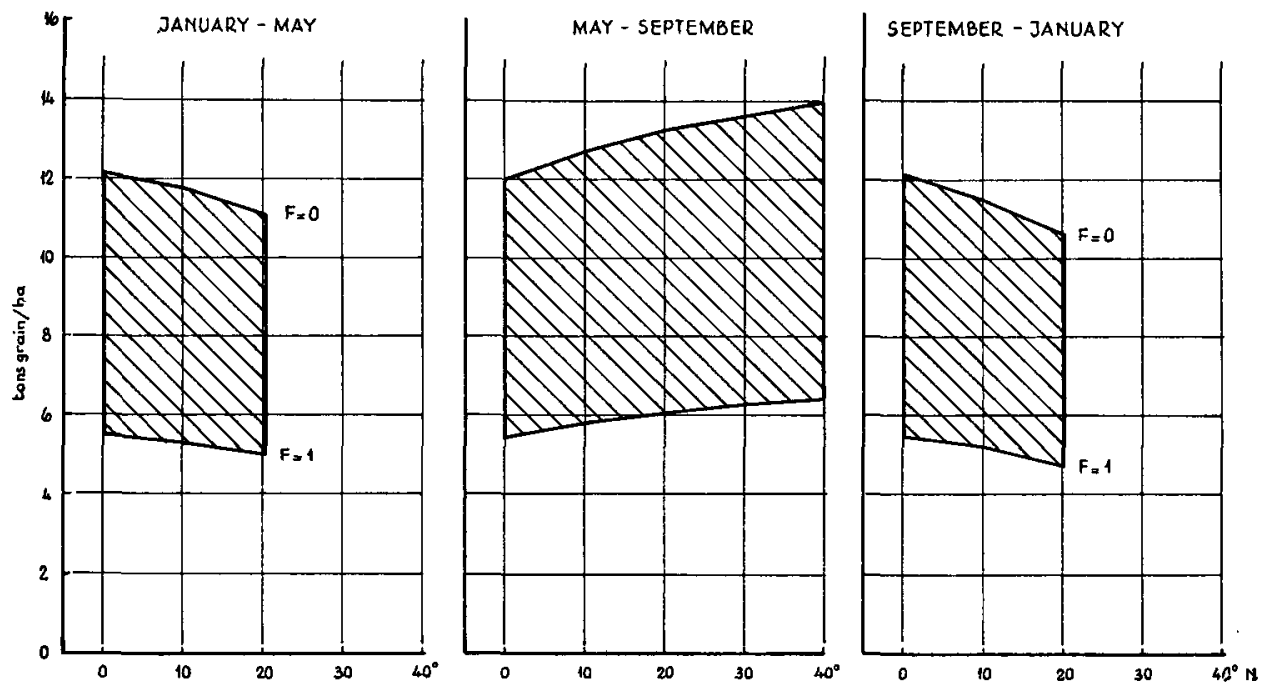

Fig. 5. Ranges of potential rice yields for a modern non-lodging variety with a constant growth cyclus at different latitudes and in different seasons. $F$ is the fraction of the day-time when the sky is overcast.

Neth. J. agric. Sci. 20 (1972) 
to the calculation method used, however, it appeared that in the poorly performing March and May plantings of 'Peta' and 'BPI-76', with a very long period of growth decrease in the generative period about $60 \%$ of the final grain originated from the pre-flowering period; this was also suggested by Tanaka et al., (1964).

This percentage does not agree with the results obtained in more recent tracing experiments in cereals, which have shown that by far the greater part of the grain is assimilated after flowering (Stoy, 1966).

In this regard, first it must be considered that in the rice grain the husk, being formed mainly before flowering, takes up about $20 \%$ of the total grain weight (Chang TeTzu and Bardenas, 1965), which is a very high value for a cereal. Secondly, carbohydrates accumulated in the pre-flowering period can be respired later on, thus leading to a lesser amount of respiration to be subtracted from the gross photosynthesis in the post-flowering period.

Although little is known in this respect, the weights given for the pre- and post-flowering periods by using the translocation percentages do not seem to be affected too much. Moreover, with a relatively short period of growth decrease at the end of the cultivation period, which is the case in modern varieties having a good $\mathrm{N}$ supply, the disagreement does not show.

\section{The modern varieties}

In the modern IRRI varieties, high photosynthetic rates (Anon., 1968) are combined with favourable morphological qualities. So high nitrogen dressings, needed for a rapid growth over a long time, do not cause lodging. For such a non-photosensitive variety with a growth cyclus supposed to be constant on all relevant latitudes, ranges for potentıal grain yields have been likewise calculated for the different seasons ${ }^{1}$ (Fig. 5). The upper limit refers to perfectly clear days $(F=0)$, the lower limit to totally overcast days $(F=1)$.

For a number of places at the relevant latitudes, the average F-values during the different seasons could be calculated from measured solar radiation (see references. Solar radiation data) by using Eq. 1. The corresponding average growth rates, dry matter productions and grain yields are given in Table 5, the differences being based only on the solar radiation effect.

\section{Discussion and conclusion}

So far, the high annual productions as calculated in Table 5 for tropical regions have been seldom realized. At the IRRI, however, annual productions of 23 ton grain per ha are reported in continucus cropping experiments (Anon., 1969), viz about 10 ton/ha in the dry season and two times 6-7 ton/ha in the rainy season. Yields of 11 ton/ha harvest are also reported from places in West-Pakistan and Kenya where solar radiation is abundant (ILACO information). Therefore, the calculations made seem to be fairly realistic.

From the economic point of view, however, in obtaining such very high yields marginal costs may largely exceed the marginal rents in the end. So thus far, as a rule of thumb, farmers' production potentials are likely to be about $25-35 \%$ below the yield potentials.

1 The translocation percentages used are those fond in 'Peta'. 
Table 6. Potential average growth rates, total dry matter productions and grain yields for every season and per year, calculated for a modern non-lodging variety with adequate $\mathbf{N}$ supply and constant growth cyclus on different latitudes.

The $F$ factor is calculated from measured solar radiation (see references: Solar radiation data) and indicates the fraction of the day that the sky is overcast.

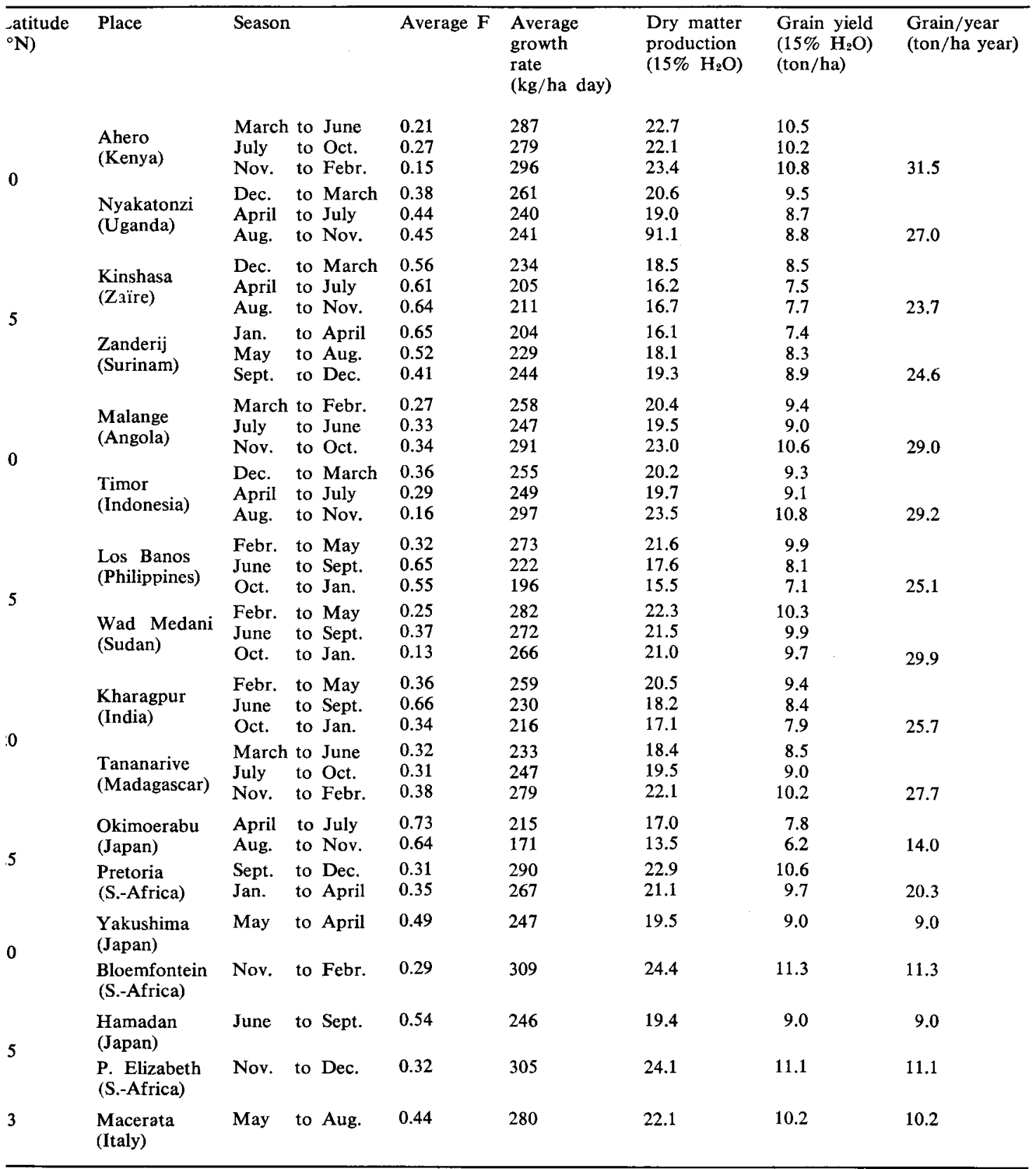


The calculation method shows that high rice yields are to be expected if a high growth rate per ha is maintained as long as possible in the generative period. This depends on climatic, crop and cultivation factors.

As far as climatic conditions are concerned, first there should be a high amount of solar radiation in the generative period; the correlation between grain yield and solar radiation during the generative period is also reported by Moomaw et al. (1967) and the IRRI (Anon., 1969). Secondly, the average temperature during the ripening period should be relatively low, since this extends the active life of the rice plant thus causing more photosynthesis for grain production (Ebata and Nagato, 1967). Moreover, de Wit et al. have recently found that lower temperatures reduce that part of the respiration that is needed for maintenance of structural proteins in existing plant tissues. Also it must be considered that in the rice plant gross photosynthesis declines sharply when temperatures exceed $33^{\circ} \mathrm{C}$ or fall below $20^{\circ} \mathrm{C}$ (Murata, 1961).

As for the crop and cultivation factors, leaves should have a high maximum photosynthesis rate (AMAX). In the vegetative stage, the plant should have sufficient leaf development and a good tillering ability, both in relation to the spacing used in order to obtain the required LAI and a high number of panicles per $\mathrm{m}^{2}$ respectively.

Relatively close spacing results in a closed crop surface within a short period of time since lesser tillering is needed; it also decreases the risk of panicle failure and the vegetative stage can be shortened by a few days (Anon., 1969).

Finally, one of the most important factors is that leaf canopies should be green as long as possible, which also guarantees the quality of the product. To this end, adequate nitrogen supply, a non-lodging plant type and relatively low temperatures during ripening are required.

\section{Acknowledgments}

The author is much indebted to Professor C. T. de Wit, who has assisted him in handling his model, to the ILACO staff members of the agronomy department for the many helpful discussions and to Dr M. Flach for criticizing the manuscript.

\section{References}

Anonymous, 1967. Rice production manual. University of Philippines, College of Agriculture, cooperation with the IRRI.

Anonymous, 1968. A. Rep. int. Rice Res. Inst., p. 24-28.

Anonymous, 1969. A. Rep. int. Rice Res. Inst.

Chang Te - Tzu \& Elise, A. Bardenas, 1965. The morphology and varietal characteristics of the rice plant. Tech. Bull. int.Rice Res. Inst. 4.

Ebata, M. \& K. Nagato, 1967. Ripening conditions and grain characteristics. IRC News. (special issue), p. 10_17.

Moomaw, J. C., P. G. Baldazo \& L. Lucas, 1967. Effects of ripening period environment on yields of tropical rice. IRC. Newsl. (special issue), p. 18_25.

Murata, Y., 1961. Studies on the photosynthesis of rice plants. Bull. nat. Inst. agric. Sci. ser. D, No 9.

Shen Lian \& A. Tanaka, 1967. Behaviour of photosynthetic products Associated with Growth and Grain Production in the rice plant. Pl. Soil 27 (2).

Solar radiation data: Annual report of the Japan Meteorological Agency, 1967; East African Meteorological Department, E. A. Community, Nairobi, 1970; Hydro-meteorological records from areas for potential agricultural development in Uganda, 1965; Il Riso 17 (2), 1968; Meteo gegevens, vliegveld Zanderij, 1970; Osservazioni meteorologichi, Anno 1969. Camera di commercio, industria, 


\section{CALCULATION OF POTENTIAL RICE YIELDS}

Arliginato ed Agricoltura, 1969; The Quarterly Radiation Bulletin, Weather Bureau of South Africa, 1970.

Stoy, V. 1966. Photosynthetic Production after Ear Emergence as Yield-limiting Factor in the Culture of Cereals. Acta Agr. Scand. Suppl. 16: 178-182.

Rice Plant in the Tropics and its Effect on Nitrogen Response. IRRI Tech. Bull, no 3.

Tanaka, A., K. Kawano, \& T. Yamaguchi, 1966. Photosynthesis, Respiration and Plant Type of the Tropical Rice Plant. IRRI Techn. Bull. no 7.

Wit, C. T. de, 1958. Transpiration and crop yields. Meded. Inst. biol. Scheik. Onderz. Landb. Gewassen 59 , p. 19.

Wit, C. T. de, 1965. Photosynthesis of leaf canopies. Agric. Res Rep. 663. 